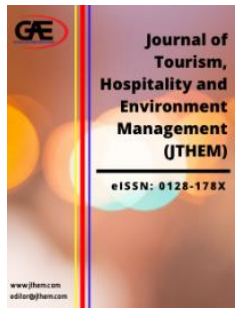

JOURNAL OF TOURISM, HOSPITALITY AND ENVIRONMENT MANAGEMENT (JTHEM)

www.jthem.com

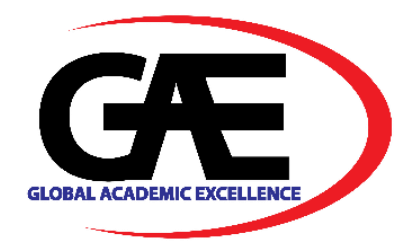

\title{
THE COMPETITIVENESS ANALYSIS OF EDIBLE BIRD NEST INDUSTRY IN MALAYSIA: APPLYING PORTER'S FIVE FORCE
}

Fatin Farazh Ya'acob ${ }^{1 *}$, Mohamad Zaim Isamail², Zahirah Hamid Ghul ${ }^{3}$, Rabiatul Munirah Alpandi ${ }^{4}$, Siti Mariam Mellisa Abdullah ${ }^{5}$

1 Faculty of Business and Management, Universiti Teknologi MARA, Cawangan Johor, Kampus Segamat, Malaysia Email: fatinfarazh@uitm.edu.my

2 Academy of Contemporary Islamic Studies, Universiti Teknologi MARA, Cawangan Johor, Kampus Segamat, Malaysia

Email: mohamadzaim@uitm.edu.my

3 Faculty of Business and Management, Universiti Teknologi MARA, Cawangan Johor, Kampus Segamat, Malaysia Email: zahir443@uitm.edu.my

$4 \quad$ School of Accounting \& Finance, Taylors University, Selangor, Malaysia

Email: munirah.alpandi@taylors.edu.my

5 Centre for Australian Degree Programs (Swinburne University of Technology), Inti International College, Subang, Malaysia

Email: melissa.abdullah@newinti.edu.my

* $\quad$ Corresponding Author

\section{Article Info:}

\section{Article history:}

Received date: 15.05 .2021

Revised date: 31.05 .2021

Accepted date: 11.06.2021

Published date: 15.06.2021

\section{To cite this document:}

Ya’acob, F. F., Isamail, M. Z., Ghul, Z. H., Alpandi, R. M., \& Abdullah, S. M. M. (2021). The Competitiveness Analysis of Edible Bird Nest Industry in Malaysia: Applying Porter's Five Force. Journal of Tourism, Hospitality and Environment Management, 6 (23), 79-92.

DOI: $10.35631 /$ JTHEM.623009.

\begin{abstract}
:
The demand for EBN is continuous to growth and about 70 percent of world demand still cannot be fulfilled. Unfortunately, Malaysia only contributes 20 percent from world demand. The aims for this industry are to contribute about RM5 billion to Malaysian agricultural export and to achieve at least 40 percent of world demand. As being one of the most demanded EBN and being in the competition for leadership in world bird nest market, it can be specified that new market entrants and investments are important to fulfil the aims of government to this industry and for the growth of EBN industry. Thus, the objectives of this paper are to analysing the current competition condition of EBN industry in Malaysia and its opportunities for new entrants. This study revealed that the need of a huge capital and knowledge to conduct this business is essential and must come together. There is relatively low threat of substitution if the business premise is a shop lot. Despite the existence of buyer power in price negotiations, swiftlet house owners too could influence the process and assure themselves of higher markups when they organise a tender process with the help of the rancher's association. Threat of rivalry is low especially with the setup of the rancher's association to help each member who faced problems.
\end{abstract}




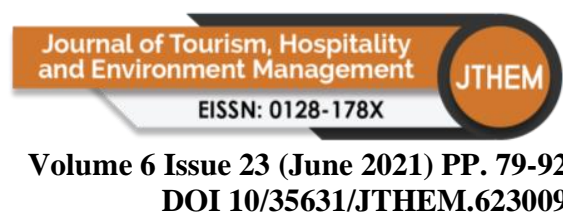

This work is licensed under $\underline{\mathrm{CC} B Y} 4.0$

()(1)

Keywords:

Swiftlet, Competitiveness, Porter Five Force, EBN

\section{Introduction}

The production of swiftlet nest is expected to increase due to continued demand from China where it's very popular among the people besides being measurement to the status of individual in China. Malaysia can become a major exporter as the development and production of Edible Bird Nest (EBN) in this country faces a rapid growth. For now, Malaysia has produced 290 metric tons and probably to increase up to 870 metric tons (ETP Report,2012).

In addition, Malaysia has a good opportunity to grab as this industry is not suitable for all climates. This is because regions such as China, Taiwan and Hong Kong, with four-season climates are not the natural habitat of the swiftlet. In other words, the world supply of bird's nest comes solely from the region of Southeast Asia. As this industry is not suitable for all climate and with the high growth rates of China market and new potential emerging market there is a constant unmatched demand for the supply of EBN.

The demand for EBN is continuous to growth and about 70 percent of world demand still cannot be fulfilled. Unfortunately, Malaysia only contributes 20 percent from world demand (Department of Veterinary Services). The aims for this industry are to contribute about RM5 billion to Malaysian agricultural export and to achieve at least 40 percent of world demand by 2020 (Economic Report, 2011). Unfortunately, this goal still cannot be achieved. Besides that, this industry was identified as one of the 16 entry point project (EPP) initiatives in the Economic Transformation Program (ETP) of Malaysia. On top of that, Malaysia EBN has better quality because our product does not have any disease and widely accepted in the international market and Malaysia has good system on track and traceability (MARDI, 2012). After China lifted the banned of edible bird nest, only Malaysia has the approval to export bird nest to China which is the largest world importer with precautionary measurement. However, the price of raw bird nest after the embargo is lower ranging from RM1,200 to RM1,500 per kilogram compared to before the embargo (RM 4,000 to RM6,000 per kilogram) and the price increase is rising very slowly.

Swiftlet farming EBN is a high-value industry inspired by the Prime Minister of Malaysia in 2007. It has been used as one of National Key Economic Areas program (NKEA) Agriculture under the MOA to achieve Gross National Income (GNI) amounted to RM4.5 billion by 2020 . Thus, to ensure this industry sustain in the long term, the level of competitiveness is important to make it comes true.

As being one of the most demanded EBN and being in the competition for leadership in world bird nest market, it can be specified that new market entrants and investments are important to fulfil the aims of government to this industry and for the growth of EBN industry. On top of that, it is a need to analyse the current competition conditions of EBN industry to determine if it is convenient for new market entrants or not as the price of raw bird nest are dropped after embargo. In addition, there is a gap in literature concerning the level of competitiveness for Malaysian EBN industry as many studies focus more on scientific research of edible bird nest 


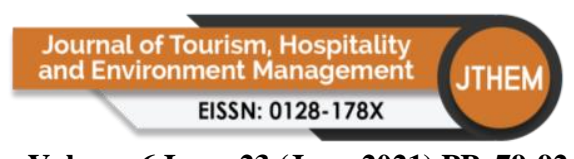

Volume 6 Issue 23 (June 2021) PP. 79-92

DOI 10/35631/JTHEM.623009

$(\mathrm{EBN})$. Specifically, the objectives of this paper are to analysing the current competition condition of EBN industry and its opportunities for new entrants.

\section{Literature Review}

Competitiveness, according to Eskandari et al (2015), is defined as a firm's success in relation to other enterprises in the industry, on a national and international scale. It can be established or improved by implementing the correct competitiveness strategy, one of which is to manage resources effectively and efficiently (Juliana \& Nyoman, 2019). Competitiveness has a positive effect on long-term economic growth (Charles et al, 2014). Over the years, competitiveness has become a goal for industries as well as economies to stimulate efficiency, development, to ensure the industry will expand, sustain and to achieve high level of performance. Moreover, competitiveness is considered as a key criterion for assessing the success of industries and they must be well competitiveness in domestic and international to survive (Gholamhossein M. et al, 2014).

Until 2020, there is many studies focus on the scientific research of edible bird nest, however investigation of business of EBN is one thing. Previous studies, such as Zulkifli (2016) focused on extraction and identification of proteins from edible bird's nest, Ghassem (2017) focused on examined the antioxidant effects of an EBN pepsin-trypsin hydrolysate and its ultrafiltration fractions from the swiftlet species Aerodramus fuciphagus, N.H. Jamalluddin, et al (2019) focused on several approaches to detect the authenticate EBN using advanced technologies and high-end instrumentations; and Mahaq (2020) focused on determination of the effects of maternal EBN supplementation on learning and memory function of their first (F1)- and second (F2)-generation mice. Besides that, there also have research on marketing and investment of EBN such as Juwaidah Sharifuddin et al (2014) focused on factors affecting intention to purchase edible bird's nest products in Malaysia, while Mohamad Shukri et al (2018) focused on modelling purchase intention towards edible bird's nest products among Malaysians, Suarni et al (2019) determine the factors that motivate the local community South Sulawesi, to engage in edible bird's nest industry. Finally, Fatin F. et al (2019) investigate the factors influencing investment decision making in swiftlet ranching industry.

The framework of Porter's Five Forces Model is intended to be described as an examination of a business's evolution. This concept can be applied to both large and small businesses, as well as businesses that are currently in operation or are just getting started. Aside from that, this model is a significant contribution to the general theory of competitiveness and competitive advantage, as well as an influential industrial analysis in the field of industrial rivalry analysis (Juliana \& Nyoman, 2019). On top of that, Porter's Five Force Model explore economic factors that affect the industry with systematically and comprehensive. There are five forces that explain industry attractiveness which are threat of new entrance, threat of substitutes, the bargaining of supplier power, the bargaining of buyer power and the degree of rivalry.

Porter's five force model is simple but powerful in explaining the power or strength of current competition model and position that the company in the industry considering moving into. This model is widely used in many different industries to analyse the competition. At the Culinary Center in Sidoarjo Regency, Ferdinand and Tresyanto (2020) study the marketing plan utilising Porter's Five Force Model. Meanwhile, Hou \& Luo (2020) study the competitiveness of distributed energy resources using the Michael Porter five forces model, concluding that enhancing the competitiveness of distributed energy resources in China is essential. Eskandari 


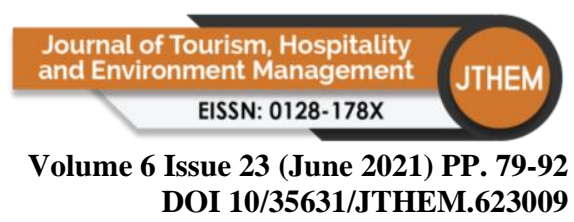

et al (2015) use Michael Porter's competitive forces model to investigate factors affecting the food industry's competitiveness in Hamadan Province, Iran. Next, Zhao et al. (2016) assessed the competitiveness of China's biomass power industry using Michael Porter's Five Forces Model theory for examining the competitive environment and competitive status of a business. Wu Yunna \& Yang Yisheng (2014) apply Porter five force in analysing the competition situation in shale gas industry in China and found that SG suppliers are in a precarious economic position in the current shale gas market of China.

Porter stated that there are five force that determine industry attractiveness and long run industry profitability which are:

\section{Threat of New Entrance}

The height of entry barriers and the reaction of new entrants determine the threat of entry in a given industry. When an industry allows new entrants to easily become competitors, it means the entry barriers are low. According to Wellner \& Lakotta (2020), the threat of entry limits the earning potential of the industry. High earnings in the business attract new firms with new capabilities and increased capacities vying for market share, putting pressure on incumbents' prices and costs. In fact, Eskandari et al (2015) believed that new entrants into an industry bring with them new capacity and tend to win market share and lead to great deal of pressure on pricing, costs, and investment rates to compete. There are two factors that can be threat of potential entrants which are barriers to entry and reaction of company in the industry with new entrants (Wu Yunna, 2014). The common variables used under entry barriers are government policy, economic of scale and capital.

\section{Threat of Substitution}

According to Goyal (2021), the threat of substitutes means the competition that is formed in the market by substitute products, and it give the same satisfaction to the consumers when they buy it. The presence of substitute products can lower industry attractiveness and profitability because they limit price levels and turn the customer to other product. The lower price or better quality, the stronger competitiveness the substitutes have (Wu Yunna, 2014). If substitution is easy and substitution is capable to working successfully, then this can weaken the industry power. The threat of substitute products depends on several factors such as buyers' willingness to substitute, the relative price and performance of substitutes, the costs of switching to substitutes (Figen and Cansu, 2012).

\section{Supplier Power}

The power of suppliers refers to the ability of bargaining power and controlling power of resources. When suppliers are small in number, offer distinctive products, and can credibly threaten to merge forward in the industry, it means they have a high of power (Goyal, 2021). Suppliers play a crucial role in the value chain of the industry and influencing critical aspects such as lead times and overall product quality (Bhatia, J., 2016). The factors contribute to the power of suppliers are the number of suppliers of each key input, the uniqueness of their product or service, their strength and control over buyers, the cost of switching from one to another, and others. 


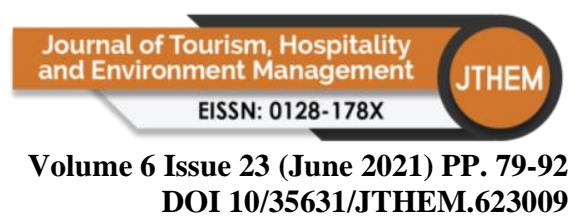

\section{Buyers Power}

This refers to the influence that purchasers have over the company. Buyers can threaten the industry by bargaining down prices or raising the costs by demanding better quality (Wu Yunna, 2014). Buyer power is one of the two horizontal forces that influence the appropriation of the value created by an industry. Buyers in certain businesses, such as those with a small number of buyers who purchase huge volumes, have a lot of bargaining power. This is especially true in businesses with high fixed costs (Goyal, 2021)

\section{Degree of Rivalry}

According to Goyal (2021), the intensity with which companies compete and the grounds on which they compete will determine how much rivalry drives down an industry's profit potential. When there is slow growth or a big number of competitors, these are likely to be high. It's can also happen when companies are unable to read each other's signals in the market. This is often the most powerful competitive force among the five competitive forces. In order for the existing rivalry attempt to gain a competitive advantage, they will be accomplished it by strategies such as pricing competition, advertising campaigns, and so on (Bhatia, J.,2016).

\section{Methodology}

\section{Description of Study Area}

The chosen area of study is Gua Musang, Kelantan. This area is a rural area that suitable with swiftlet habitat because of the geographic factors where there has cave, oil palm plantation, rubber cultivation and forest that unexplored yet. The stakeholder in this study are ranchers because they are very affected after embargo. A list of ranchers is obtained from Department of Veterinary Services (DVS) and about 100 ranchers are chosen as respondents to be interview through simple random sampling with replacement method in Gua Musang, Kelantan.

\section{Data Collection}

To answer the research question, a structured interview was conducted by using questionnaires. The draft questionnaire was pre-tested at the study sites before starting the actual data collection. It provides a trial run for the questionnaire, which involves testing the wordings of question, identifying ambiguous questions and testing the techniques that used to collect data. A team of three experienced enumerators visited the study area to get information from the respondents. Trainings were given to the enumerators to acquaint them with the objectives of the study and purpose of the survey before and during the fieldwork data collection process.

\section{Questionnaire Design}

The questions were divided into two sub-headings with the first one specifically targeted at gathering data about the general background of the firms or respondent. The second subheadings of the questionnaire consisted of mainly questions which sought information on the determinants of Porter's five force model as a tool to testing industry competitiveness. The questionnaire has 25 questions where each questionnaire is scored on a 7-point likert scale ranging from 1 to 7 . The questionnaire is adapted from previous research Ucmak \& Arslan (2012) and have been modified to answering the objective. The respondent then was asked to describe in detail the reason of their rating. 


\section{Data Analysis}

Analysis of data started with data sorted, coded and accurately fed into the SPSS program for computerized analysis to generate descriptive statistics such as frequencies and percentages then present them through frequencies and percentage tables. Reliability of data was analyse using Cronbach Alpha.

\section{Result and Discussion}

\section{Threat of New Entrants}

Perspectives on the threat of new entrants or barriers varied among those who are already in this industry in comparison to potential new entrants into this industry. Potential new entrants face many entry barriers that are difficult to overcome. Based on the interview, barriers to entry can be grouped into high capital requirement, long payback period and lack of knowledge on EBN.

\section{Capital Requirement}

Capital requirement is the most important entry barrier into the EBN industry as it needs huge capital to build a swiftlet house costing around RM120 thousand for 3 storeys $(20 \times 40)$ to RM200 thousand for 3 storeys (20x60) depending on the size of swiftlet house. The cost to build the swiftlet house if a consultant is engaged can take up to RM400 - RM415 thousand for 3 storey houses. All these costs are not inclusive of the cost of land because most of them build this swiftlet house on their own land.

From the table below, 66.34 percent ranchers agree that capital needed to enter this business is high while 25.74 percent strongly agree with this statement. So, the amount of capital needed to enter this business was found to be high. Besides that, capital needed to expand the business also found to be high as 65.35 percent agreed and 26.73 percent strongly agreed.

Table 1: Threat of New Entry

\begin{tabular}{lccccccc}
\hline & 1 & 2 & 3 & 4 & 5 & 6 & 7 \\
\cline { 2 - 7 } & $\%$ & $\%$ & $\%$ & $\%$ & $\%$ & $\%$ & $\%$ \\
\hline $\begin{array}{l}\text { Capital needed to enter } \\
\text { Capital expansion }\end{array}$ & 0 & 0 & 0 & 0 & 7.92 & 66.34 & 25.74 \\
$\begin{array}{l}\text { Time to become } \\
\text { profitable }\end{array}$ & 0 & 0 & 0 & 1.98 & 37.62 & 60.40 & 0 \\
$\begin{array}{l}\text { Knowledge \&experience } \\
\text { Technology }\end{array}$ & 0 & 0 & 0 & 0 & 0 & 67.33 & 32.67 \\
Government role & 3.96 & 27.72 & 64.36 & 3.96 & 0 & 0 & 0 \\
\hline
\end{tabular}

Evaluation levels were defined as the following: 1: strongly disagree, 2: disagree, 3: somewhat disagree, 4: nuetral, 5: somewhat agree, 6: agree, 7: strongly agree.

Most of the investors self-financed their initial capital through by self-financing, while the rests through semi-personal loans and full personal loans. For those ranchers that took personal loans, repayments from RM1,240 to RM2,000 per month for 4 to 5 years are required.

There are various cost components within the capital investments of a swiftlet house. For nesting planks with a distance of 17 to 18 inches from each plank, the cost is around RM10 thousand for a 3 -storey house. For nesting planks with a distance of 6 inches between planks, the costs are higher. Three units of amplifier are needed for each 3-storey house with each costing RM500 per amplifier with a total of RM1,500. Within each swiftlet house, around 100 Copyright $\odot$ GLOBAL ACADEMIC EXCELLENCE (M) SDN BHD - All rights reserved 


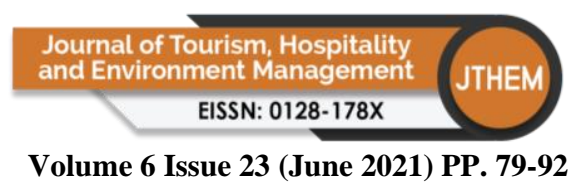

Volume 6 Issue 23 (June 2021) PP. 79-92

DOI 10/35631/JTHEM.623009

speakers are needed per storey costing around RM1,200. For new swiftlet house, four units of main speakers are needed costing around RM120 per unit to attract swiftlets into their new home. Further, MP3 CDs to attract the swiftlets to live and nest in their new home would cost around RM1,000 for the three types of sounds. In addition, the audio system needs a timer and the cost is RM60 per unit. For safety reasons, some swiftlet ranchers install CCTV around the house and it costs around RM500 to RM6,000 for 3 units of CCTV. On top of the high investment cost, each of swiftlet house have their own maintenance cost which include repairing wiring, speakers and timer if there have any damage. This maintenance can cost around RM300 to RM500 per month depending on the equipment. Below is an illustration of a high capital needed in this industry:

"Most of the ranchers are not using consultant so that we can save money (because we make loan from bank) but a few ranchers who have extra money they used consultant. To start up this swiftlet house I need at least RM200 thousand as my swiftlet house is 3 storeys. For me it is a huge investment not all people want to take risk to involve in this business"

(From rancher)

\section{Time to Become Profitable}

Payback period can be an essential influence on new investors into the EBN industry. From the table 1 above, 60.4 percent of ranchers agreed that it take a long time to become profitable while 37.62 percent slightly agreed. From the interview, most of the ranchers takes around 2 to 3 years to breakeven. This is depending on how many swiftlets comes and nesting in their new homes.

"It takes one month for the swiftlet to comes to the house and three months for them to nesting. After six months we can start collecting the nest. Average the swiftlet lives in the house is 800 to 1000 birds"

(From rancher)

However, there is a case where in 2 years' time only few swiftlets nesting and the rancher still cannot sell the EBN and still cannot breakeven. An illustration provided below:

"My swiftlet house still doesn't have good production. I still cannot get breakeven even the house already 2 years operation. Only few swiftlets comes and nest there. There are few reasons. First, the location is not strategic because I do not test first the location before build the house. Second, there is another swiftlet house near the location. Third, I'm not give full attention to the house as he has another business to focus. I do not check and do not do the maintenance to the house."

(From rancher)

\section{Knowledge}

The lack of knowledge of the science and business of EBN is another big barrier to entry. To successfully enter this industry, investors must have a good understanding of the knowledge of this industry. From the table 1 above, 67.33 percent of rancher agreed that knowledge and experience are important and helpful in production of bird nest and 32.67 percent of ranchers strongly agreed. 


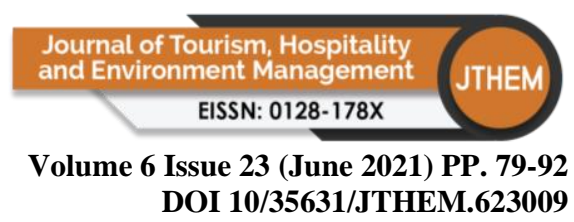

As there is no specification or standard of operation (SOP) to construct the swiftlet house, many ranchers agreed that to start this business line they need special knowledge on how to build a successful house. An illustration provided below:

"First, the location of the house needs to be strategic. We need to test the location of house to see either there are swiftlets comes and the direction/ways they come also the rancher need to understand. The sound that plays to attract swiftlet is one of the important factors. After built the house, the temperature and humidity level also need to be right level. We must think how to protect the swiftlet from predators. We need to try and error because sometimes the protection can kill the swiftlet."

(From rancher)

In term of to increase production, the ranchers need to know the timing of harvest. All these knowledges, most of the ranchers learn from their friends who already have many experiences in this field. Despite, the high barrier to entry discussed above, there are several factors leading to low barriers of entry.

There is no high technology needed to construct a swiftlet house. In the minds of ranchers, what are necessary is to choose the right sound to be play for the main speaker to attract more swiftlet into the house and another to encourage nesting in their new homes. This is because the wrong sound will not attract that swiftlet but can irritate them to the extent of a fight making swiftlets feeling that the house is unsafe for them to live.

"Swiftlet house no need a high technology, just speaker, timer, a right sound, humidifier, and protection for them. That's all."

(From rancher)

\section{Government Policy or Role}

There is no standard of proceeding (SOP) from government to build swiftlet house. However, DVS in a way to make sure all ranchers to register their house with DVS so that DVS can put RFID at their swiftlet house. Interviewed DVS officer expressed that; RFID will help us to trace which swiftlet house that produce bird nest if there is some problem happen like last July 2011. Thus, it will help Malaysia EBN to improve its quality and it's also can increase China level of trust to us. However, many ranchers do not want to install it because they do not realise the important of this RFID. According to the ranchers interviewed, RFID does not give any benefit to them. Many ranchers promised by buyers to increase the price of bird nest if their swiftlet house have RFID but it's just a promised. No difference between ranchers who install RFID at their swiftlet house and who don't install it. So, they make decision not to install it.

"I already go for seminar three times from DVS, but I don't know what the use of RFID because it doesn't give me any advantages from other ranchers who don't install it. So, for me it doesn't have any function and I don't see it."

(From rancher)

Beside RFID, government also establish 1GP which is industrial guideline for bird nest and establish MyGap Scheme to monitoring swiftlet house every year to see the level of cleanliness. Interviewed DVS officer expressed that; in Gua Musang, ranchers rarely go to DVS to 


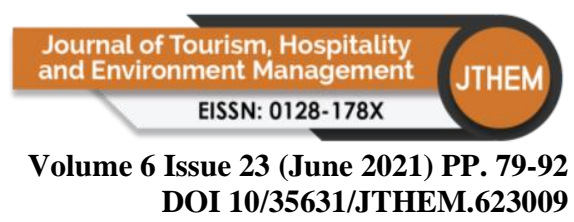

complaint or ask for help if they faced problem regarding their swiftlet house. They will go straight to the head of rancher association or expert ranchers to get some help.

"We don't receive any complaint from ranchers because they know who they will called if there is problem with their swiftlet house. Regularly, ranchers will call head of rancher association to help them regarding their swiftlet house"

(From Puan Hafizah: Director Gua Musang DVS)

According to the ranchers interviewed, they do not burden with DVS policy but the things that make them hard to run this business is the Gua Musang Local Council policy. This is because, Gua Musang local council interferes very much of their bird house operation. Here, ranchers need to pay RM1,000 per year for every swiftlet house to them. Besides that, ranchers need to get approval from them before build the bird house. They need to prepared iron plan which is RM1 for 1 square feet.

"Most of ranchers have no problem with DVS. However, what we not satisfied with Majlis Perbandaran because they always disturb our business even we already pay fees RM1000 per year."

(From Head of Rancher Association)

In 2010, government establish E-Kasih where give loan RM10,000 to retires and villager who interested to run this business. Unfortunately, most of them are failed due to several factors. As conclusion, district council with their interfere, policy and fees give high barrier for ranchers to operate this business.

\section{Threat of Substitution}

Table 2: Respond for Threat of Substitution

\begin{tabular}{lccccccc}
\hline & 1 & 2 & 3 & 4 & 5 & 6 & 7 \\
\cline { 2 - 8 } & $\%$ & $\%$ & $\%$ & $\%$ & $\%$ & $\%$ & $\%$ \\
\hline $\begin{array}{l}\text { Availability of } \\
\text { substitutes }\end{array}$ & 0 & 0 & 8.91 & 23.76 & 52.48 & 14.85 & 0 \\
$\begin{array}{l}\text { Cost of } \\
\text { substitutes }\end{array}$ & 0 & 11.88 & 51.49 & 23.76 & 12.87 & 0 & 0 \\
$\begin{array}{l}\text { Market of } \\
\text { substitutes }\end{array}$ & 0 & 11.88 & 49.50 & 31.68 & 6.93 & 0 & 0 \\
\hline
\end{tabular}

Evaluation levels were defined as the following: 1: strongly disagree, 2: disagree, 3: somewhat disagree, 4: neutral, 5: somewhat agree, 6: agree, 7: strongly agree.

The level of substitution of economic activities is mixed depending on where the investment is made. Most of the ranchers on agricultural land expressed that they have several alternative investment opportunities on their land such as oil palm cultivation, fruit orchards and aquaculture. But what is interesting is that these alternative agricultural activities complemented swiftlet ranching. Besides that, ranchers who built swiftlet houses at shop lots, can renovate back and rent their premises when the swiftlet house project is abandoned. There is a high willingness to substitute from one business to another because most of them have additional cash and are willing to bear the cost of renovations. This is because for them to avoid from further losses, they would rather spend a little more money for renovation to earn rental incomes. However, in the long term they preferred to do ranching as it promises more profit Copyright (C) GLOBAL ACADEMIC EXCELLENCE (M) SDN BHD - All rights reserved 


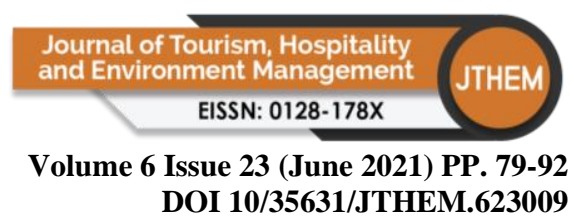

compared to others. Hence, it can be concluded that there are still flexibility and complementarity once the investments are made. An illustration provided below:

"If one day my swiftlet house does not have production, I willing to spend a little bit money to renovate my shophouse to rent it or sell it. However, in the long run I prefer this business because it give more profit than rent it."

(From Mr. Yap)

Supplier Power

Table 3: Respond for Supplier Power

\begin{tabular}{lccccccc}
\hline & 1 & 2 & 3 & 4 & 5 & 6 & 7 \\
\cline { 2 - 8 } & $\%$ & $\%$ & $\%$ & $\%$ & $\%$ & $\%$ & $\%$ \\
\hline Used consultant & 0 & 12.87 & 71.29 & 8.91 & 6.93 & 0 & 0 \\
Specific supplier & 0 & 20.79 & 76.24 & 2.97 & 0 & 0 & 0 \\
Change supplier & 0 & 0 & 0 & 0 & 24.75 & 62.38 & 12.87 \\
\hline
\end{tabular}

Evaluation levels were defined as the following: 1: strongly disagree, 2: disagree, 3: somewhat disagree, 4: neutral, 5: somewhat agree, 6: agree, 7: strongly agree.

For the ranching industry, in general there are no outright supplier power except in specific and special cases. The rancher does not need to provide any swiftlet food instead what is needed is to just provide the necessary equipment such as nesting plank, internal and external audio, mist spray and safety concern of the house. This necessary equipment does not need frequent changes unless there is a breakdown. Further, the rancher can buy any of the equipment (such as speakers which are prone to damage) anywhere as it is widely available and do not require going to specific suppliers. However, to build the swiftlet house, require a qualified swiftlet house builder. Many ranchers have acted on their own to build their swiftlet houses by procuring their own construction materials and then engaging general workers to construct their swiftlet houses. In other cases, due to a lack of knowledge on the science and business of EBN, there are investors who engaged consultants or relied on friendly advice which may not necessarily be confirmed and verified. As mentioned earlier the lack of a standard operating procedure of EBN swiftlet house construction, expose the ranchers to unscrupulous consultants and contractors. In this light high supplier power does exist in the establishment of the swiftlet houses but once properly built, the owner's reliance on the suppliers is much reduced.

"I don't go to any specific supplier because all these equipment available at any DIY shops and its don't difficult to get. Besides that, the price is similar and don't have big gap from others seller "

(From rancher)

\section{Buyer Power}

The number of buyers of raw EBN for each of ranchers varies. On average, the number of buyers is 2 to 3 for each rancher with a majority dominated racially by Chinese. These buyers are mainly from out of state. There are several reasons for the interests from out of state buyers. Among these reasons are the size and colour of the raw EBN. The size is quite big in comparison from those in the South Malaysian states such as Johor and Negeri Sembilan. and the colour of EBN is white and does not contain many feathers. Thus, it is easy to clean, and the weight is high. Some of the ranchers do not want play with the price and just follow the 
buyers' price because they are regular buyers, and the buyers comes with their own to buy from them.

However, there was a case where the rancher has 20 buyers throughout Malaysia and the rancher will undertake a tender process to sell his EBN. This tender is organised by the association of ranchers in Gua Musang. Buyers who can bid prices beyond the reservation price set by the rancher will get to win the EBN. In that situation, the reservation price of EBN was RM1,600 per kg (May 2015) and from the tender, the rancher managed to raise the price to RM1700 per kg.

Table 4: Respond for Buyers Power

\begin{tabular}{lccccccc}
\hline & 1 & 2 & 3 & 4 & 5 & 6 & 7 \\
\cline { 2 - 7 } & $\%$ & $\%$ & $\%$ & $\%$ & $\%$ & $\%$ & $\%$ \\
\hline $\begin{array}{l}\text { Number of buyers } \\
\begin{array}{l}\text { Rancher markup } \\
\text { price }\end{array}\end{array}$ & 0 & 0 & 33.66 & 10.89 & 55.45 & 0 & 0 \\
$\begin{array}{l}\text { Rancher change } \\
\text { buyer }\end{array}$ & 0 & 4.95 & 16.83 & 2.97 & 70.30 & 4.95 & 0 \\
$\begin{array}{l}\text { Buyer switch } \\
\text { rancher }\end{array}$ & 0 & 2.97 & 9.90 & 20.8 & 41.58 & 24.75 & 0 \\
\hline
\end{tabular}

Evaluation levels were defined as the following: 1: strongly disagree, 2: disagree, 3: somewhat disagree, 4: neutral, 5: somewhat agree, 6: agree, 7: strongly agree.

"Once in a month our association will do a tender to sell the nest. So, the ranchers who have bird nest can join us. Because some buyers will play price with us and offer below the standard price so by doing this tender at least we can markup a bit price as standard. If buyers do not agree with our price, then they will return with no birds nest."

Hence, buyer power is a function of the quantity and colour of the owner's EBN and mode of selling.

Response got from regular buyer stated that; "there are many ranchers from south Malaysia call us to sell their bird nest, but I prefer here first because the quality is good compared to others state and when harvest season comes, I will call them to ask when I can pick up the bird nest."

\section{Rivalry}

Table 5: Respond for Rivalry

\begin{tabular}{|c|c|c|c|c|c|c|c|}
\hline & 1 & 2 & 3 & 4 & 5 & 6 & 7 \\
\hline & $\%$ & $\%$ & $\%$ & $\%$ & $\%$ & $\%$ & $\%$ \\
\hline $\begin{array}{l}\text { Undistribution of } \\
\text { power }\end{array}$ & 0 & 0.99 & 13.86 & 24.75 & 41.58 & 18.81 & 0 \\
\hline $\begin{array}{l}\text { Possibility rancher to } \\
\text { Growth }\end{array}$ & 0 & 0 & 0 & 0 & 46.53 & 45.54 & 7.92 \\
\hline $\begin{array}{l}\text { Competitors increase } \\
\text { pressure }\end{array}$ & 9.9 & 51.49 & 38.61 & 0 & 0 & 0 & 0 \\
\hline
\end{tabular}




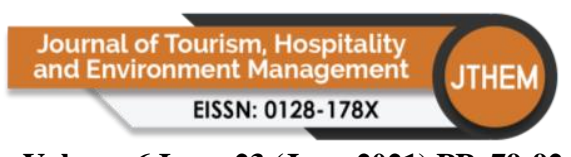

Volume 6 Issue 23 (June 2021) PP. 79-92

DOI 10/35631/JTHEM.623009

Evaluation levels were defined as the following: 1: strongly disagree, 2: disagree, 3: somewhat disagree, 4: neutral, 5: somewhat agree, 6: agree, 7: strongly agree.

The number of swiftlet houses have been increasing year by year. Until 2015 there are 200 swiftlet houses near Gua Musang and Chiku (DVS Gua Musang). According to the experienced ranchers interviewed, the number of houses is expected to increase due to rising demand from buyers. To benefit from this demand, it is necessary to make new investment. To those ranchers who have extra money, they already have several swiftlet houses and still have intentions to increase investment to add another house. This business is claimed to have a good future if investors know the strategic location and special knowledge to build the houses. However, he said that there are certain risks to be borne such as environmental problems from smoke and hazard, and occurrence of flood like the case of the December 2014 which can reduce the population of swiftlet. According to the ranchers interviewed, there is no enemies or bad competition if other ranchers want to build a new swiftlet house near to our swiftlet house because swiftlet is loyal. Once they live in one house, they will live until they died. Thus, there is no worried if new rancher wants to build swiftlet house near to us. The rising number of swiftlet houses indicates that there are low barriers to entry in this business. Rivalry among ranchers is low owing to the availability of buyers and help from the rancher's association.

The unbalance distribution of power among ranchers is quite high because the ranchers who are already expert and has long been in this industry has great advantage compared to others as they have more experience, and their house also has long been built. According to the experts interviewed, the difference in power between the expert and middle ranchers is the expert ranchers or ranchers who has been long in this industry's swiftlet house has many swiftlets compared to others, thus their productivity and profit is high.

As conclusion, rivalry is a middle barrier to entry as the association of ranchers will discuss and help those ranchers who has problems regarding swiftlet house or selling the bird nest even the number of swiftlet house is expected to increase. The experts and experience ranchers will help others but in term of productivity and profit, the expert and experience ranchers have more advantage.

\section{Conclusion}

This study that relies on the interview and direct feedbacks from ranchers, have shown several important characteristics concerning the competitiveness of the swiftlet industry. Among the salient features are:

i. There is no barrier of entry into the industry but there are barriers of entry for potential new investors in terms of the high capital investments and knowledge of the setting up and management of the swiftlet houses. The need of a huge capital and knowledge to conduct this business is essential and have to come together. Capital without knowledge cannot ensure survivality while knowledge without capital would not permit the business to take off.

ii. There is relatively low threat of subsitution if the business premise is a shop lot. The swiftlet houses can be reconverted back as rental housing. The same cannot be said of dedicated swiftlet houses. The alternative investments into agricultural plantations, fishery aquaculture can complement with the swiftlet houses.

iii. Despite the existence of buyer power in price negotiations, swiftlet house owners too could influence the process and assure themselves of higher markups when they organise a tender process with the help of the rancher's association. 


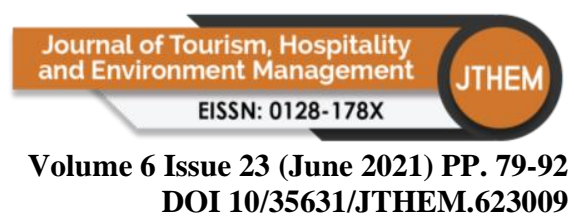

iv. Threat of rivalry is low especially with the set up of the ranchers association to help each member who faced problems.

\section{References}

Bhatia, J. (2016). Porter's Five Forces Industry Analysis of Indian Passenger Car Industry. Pacific Business Review International, 8(7), 113-123.

Eskandari, M. J., Miri, M., Gholami, S., \& Nia, H. R. S. (2015). Factors affecting the competitiveness of the food industry by using porter's five forces model case study in Hamadan Province, IRAN. Journal of Asian Scientific Research, 5(4), 185-197.

Fatin, F., Othman, M. S. H., Alpandi, R. M., Abdullah, S. M. M., \& Ghazali, M. H. (2019). Factors Influencing Investment Decision Making in Swiftlet Ranching Industry: The Case Of Gua Musang And Johor Bahru. Journal of Tourism, 4(16), 27-38.

Ferdinand, D. Y. Y., \& Tresyanto, C. A. (2020). Marketing Strategy Using Porters Five Force Model Approach: A Case Study at The Culinary Center In Sidoarjo Regency. International Journal of Business and Management Invention (IJBMI), 9(11), 44-48.

Ghassem, M., Arihara, K., Mohammadi, S., Sani, N. A., \& Babji, A. S. (2017). Identification of two novel antioxidant peptides from edible bird's nest (Aerodramus fuciphagus) protein hydrolysates. Food \& function, 8(5), 2046-2052.

Goyal, A. (2021). A Critical Analysis of Porter's 5 Forces Model of Competitive Advantage. Goyal, A.(2021). A Critical Analysis of Porter's, 5.

Hou, J., Wang, C., \& Luo, S. (2020). How to improve the competitiveness of distributed energy resources in China with blockchain technology. Technological Forecasting and Social Change, 151, 119744.

Jamalluddin, N. H., Tukiran, N. A., Fadzillah, N. A., \& Fathi, S. (2019). Overview of edible bird's nests and their contemporary issues. Food Control, 104, 247-255.

Juliana, J. P. E., \& Nyoman, Y. N. (2019). Factors Influencing Competitiveness of Small and Medium Industry of Bali: Porter's Five Forces Analysis. Russian Journal of Agricultural and Socio-Economic Sciences, 89(5).

Mahaq, O., P. Rameli, M. A., Jaoi Edward, M., Mohd Hanafi, N., Abdul Aziz, S., Abu Hassim, H., ... \& Ahmad, H. (2020). The effects of dietary edible bird nest supplementation on learning and memory functions of multigenerational mice. Brain and behavior, 10(11), e01817.

Mohamad Shukri, N. N. H., Mohd Nawi, N., Abdullah, A. M., \& Man, N. (2018). Modeling purchase intention towards edible bird's nest products among Malaysians. International Food Research Journal, 25(2), S165-S171.

Muhammad, N. N., Babji, A. S., \& Ayub, M. K. (2015, September). Antioxidative activities of hydrolysates from edible birds nest using enzymatic hydrolysis. In AIP Conference Proceedings (Vol. 1678, No. 1, p. 050038). AIP Publishing LLC.

Safari, N., Farhang, M., \& Rajabzadehyazdi, E. (2016). The study on the competitive status of construction companies based on Michael Porter's five competitive forces (Case study: Armeno Project Development and Management Company). European Online Journal of Natural and Social Sciences: Proceedings, 5(3 (s)), pp-72.

Suarni, A., Asriati, A., Masnan, S., \& Fitriani, F. (2019). Factors Motivating the Local Community of Belawa, Wajo Regency, South Sulawesi Province to Engage in Edible Bird's Nest Industry In The Perspective of Islamic Business Ethics. Muhammadiyah International Journal of Economics and Business, 2(2), 183-194.

Wellner, S., \& Lakotta, J. (2020). Porter's Five Forces in the German railway industry. Journal of Rail Transport Planning \& Management, 14, 100181. 
Volume 6 Issue 23 (June 2021) PP. 79-92 DOI 10/35631/JTHEM.623009

Zhao, Z. Y., Zuo, J., Wu, P. H., Yan, H., \& Zillante, G. (2016). Competitiveness assessment of the biomass power generation industry in China: A five forces model study. Renewable Energy, 89, 144-153.

Zukefli, S. N. B. (2016). Extraction And Identification of Proteins from Edible Bird's Nest. 